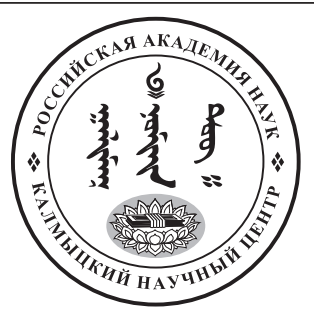

Published in the Russian Federation

Oriental Studies (Previous Name: Bulletin of the Kalmyk Institute

for Humanities of the Russian Academy of Sciences)

Has been issued as a journal since 2008

ISSN: 2619-0990; E-ISSN: 2619-1008

Vol. 13, Is. 3, pp. 521-532, 2020

DOI: $10.22162 / 2619-0990-2020-49-3-521-532$

Journal homepage: https://kigiran.elpub.ru

УДК 947(470.57)

DOI: $10.22162 / 2619-0990-2020-49-3-521-532$

\title{
Смертность мусульманского населения Южного Урала в 1860-1910-е гг. (особенности половозрастной структуры)
}

\section{Шамиль Наилевич Исянгулов}

${ }^{1}$ Институт истории, языка и литературы Уфимского федерального исследовательского центра РАН (д. 71, пр. Октября, 450054 Уфа, Российская Федерация)

кандидат исторических наук, старший научный сотрудник

iD 0000-0001-5691-5566. E-mail: isangul-schamil@mail.ru

\author{
(C) КалмНЦ РАН, 2020 \\ (С) Исянгулов Ш. Н., 2020
}

Аннотация. Введение. В статье рассматривается половозрастная структура умерших лиц мусульманского вероисповедания Оренбургской и Уфимской губерний во второй половине $\mathrm{XIX}$ - начале XX в. Целью исследования является определение особенностей половозрастной структуры умерших лиц - мусульман Оренбургской и Уфимской губерний во второй половине XIX - начале XX в. Материалы и методы. Основными источниками стали статистические сведения, опубликованные Центральным статистическим комитетом МВД Российской империи. В ходе исследования применялись статистический, описательный, сравнительноисторический методы исследования. Результаты. Результаты исследования показывают, что уровень смертности мусульманского населения Южного Урала в рассматриваемый период определялся младенческой и детской смертностью. Статистические материалы свидетельствуют, что удельный вес младенческой смертности у мусульман был намного ниже, чем у православных. Данное обстоятельство объясняется тем, что башкирки и татарки кормили младенцев грудным молоком до 2 лет, относительно поздно начинали прикармливать. Высокая детская смертность обуславливала в свою очередь высокий уровень рождаемости. Мальчиков в детском возрасте всегда умирало больше, чем девочек. Положение менялось после 15-летнего возраста. В возрасте 15-45 лет женщин-мусульманок умирало больше, чем мужчин. Затем, после 45 лет вновь повышалась мужская смертность. Характерными чертами смертности у мусульман были: относительно низкий удельный вес младенческой смертности (по сравнению с православным населением), высокий уровень детской смертности, повышенная женская смертность в фертильном возрасте, превышающая мужскую иногда в несколько раз, и другие. Bbыводы. Материалы исследования показывают, что уровень смертности мусульманского населения Оренбургской и Уфимской губерний во второй половине XIX - начале XX в. всегда был ниже, нежели у всего населения региона, в том числе у православного. Делается вывод, что демографический переход, то есть переход от многодетной к малодетной семье, у мусульманских народов края еще не начался. 
Ключевые слова: мусульмане, смертность, Оренбургская губерния, Уфимская губерния, половозрастная структура

Благодарность. Исследование проведено в рамках государственной субсидии проект «Духовная культура тюркских народов Южного Урала» (номер госрегистрации: АААА-А17-117040350082-3).

Для цитирования: Исянгулов Ш. Н. Смертность мусульманского населения Южного Урала в 1860-1910-е гг. (особенности половозрастной структуры) // Oriental Studies. 2020. Т. 13. № 3. C. 521-532. DOI: 10.22162/2619-0990-2020-49-3-521-532

UDC 947(470.57)

DOI: $10.22162 / 2619-0990-2020-49-3-521-532$

\title{
Mortality Rates among Muslim Population of the Southern Urals, 1860s - 1910s: an Insight into the Gender and Age Structure
}

\author{
Shamil N. Isyangulov ${ }^{1}$ \\ ${ }^{1}$ Ufa Federal Research Centre of the RAS (71, Oktyabrya Ave., Ufa 450054, Russian Federation) \\ Cand. Sc. (History), Senior Research Associate \\ iD 0000-0001-5691-5566. E-mail: isangul-schamil@mail.ru
}

(C) KalmSC RAS, 2020

(C) Isyangulov Sh. N., 2020

\begin{abstract}
Introduction. The article discusses the sex and age structure of deceased Muslim individuals in Orenburg and Ufa Governorates in the mid- $19^{\text {th }}-$ early $20^{\text {th }}$ centuries. Goals. The study aims to identify certain characteristics of sex and age structure thereof during the period under consideration. Materials and Methods. The paper mainly analyzes statistical data published by the Central Statistical Committee affiliated to the Ministry of Internal Affairs of the Russian Empire. Statistical, descriptive, and comparative-historical research methods were employed. Results. The study shows that the mortality rate of Muslim population of the Southern Urals in the examined period was significantly determined by infant and child mortality. Statistical data show that the level of infant mortality among Muslims was much lower than that among Orthodox Christians. This is explained by that Bashkir and Tatar women fed infants with breast milk all the way up to the age of 2, and introduced complementary feeding at relatively late stages. However, high child mortality rates resulted in high birth rates. In childhood, boys tended to die more often than girls. The situation changed after the age of 15. At the age of 15-45, mortality rates among Muslim women turned higher than those among men. Still, after the age of 45, male mortality increased again. Characteristic features of mortality among Muslims were as follows: a relatively low level of infant mortality (compared to that of Orthodox Christians), a high level of child mortality, increased mortality among fertile-aged women which sometimes proved several times as large as that among men of the same age, and others. Conclusions. The research materials demonstrate that mortality rates of Muslim population of the Orenburg and Ufa Governorates in the mid- $19^{\text {th }}-$ early $20^{\text {th }}$ centuries were consistently lower than those of the entire population of the region, including Orthodox Christians. It is concluded that the demographic transition, i.e. the transition from a large to small family, among the Muslim peoples of the region had not yet begun then.

Keywords: Muslims, mortality, Orenburg Governorate, Ufa Governorate, gender and age structure Acknowlegdements. The reported study was funded by government subsidy — project name 'Turkic Peoples of the Southern Urals: Spiritual Culture' (state reg. no. AAAA-A17-117040350082-3).

For citation: Isyangulov Sh. N. Mortality Rates among Muslim Population of the Southern Urals, 1860s - 1910s: an Insight into the Gender and Age Structure. Oriental Studies. 2020. Vol. 13(3): 521-532. (In Russ.). DOI: 10.22162/2619-0990-2020-49-3-521-532
\end{abstract}




\section{Введение}

Известно, что в дореволюционной России отмечалась высокая смертность населения. Данное утверждение всецело относится и к мусульманскому населению Южного Урала: башкирам, татарам, мишарям и тептярям. Однако в половозрастной структуре умерших лиц у мусульман были свои особенности.

В изучении темы еще в дореволюционный период были сделаны интересные выводы. Так, в пореформенный период ряд представителей гуманитарной общественности высказывал мысли о вымирании башкир. К числу таких исследователей относились В. М. Флоринский, Л. П. Сабанеев, Г. И. Успенский и др. [Флоринский 1874: 763-765; Сабанеев 1873: 7; Успенский 1982: 15-18]. Между тем, многие их современники (Н. А. Гурвич, Н. Л. Скалозубов, Д. П. Никольский и др.) отрицали факт вымирания башкир. При этом они опирались и на статистические сведения. Так, Н. Л. Скалозубов, рассмотрев смертность в 30 мусульманских приходах Красноуфимского уезда Пермской губернии за 5 лет (в 18871891 гг.), пришел к выводу, что смертность у них была намного ниже, чем у православных, и вообще мусульмане отличались низкой смертностью [Скалозубов 1893: 22].

Д. П. Никольский, рассмотрев смертность башкирского населения в трех волостях Пермской губернии в 1870-1885 гг., пришел к выводу, что она была ниже, чем в ряде русских уездов. Половина общего числа умерших приходилась на детей в возрасте до 5 лет. Однако данный процент, по сравнению с другими национальностями России, был также ниже. Несмотря на то, что смертность детей в возрасте до 1 года составляла наибольший процент в возрастной структуре смертей, но он все же у башкир был ниже, иногда в 2 раза, чем в русских губерниях. Он данное явление объясняет тем, что башкирки до 1,5 лет, а иногда до 2-2,5 лет кормили детей грудным молоком, поздно начиная их прикармливать. Во время кормления грудью мать берет ребенка всегда, «куда бы она ни ехала, в поле ли, на работу или в гости» [Никольский 1899: 124]. Все это снижало младенческую смертность. По мнению автора, в детском возрасте девочек умирало больше, нежели мальчиков. Женщин же в возрасте 26-50 лет умирало больше, чем мужчин, после 50 лет (до 80 лет) - наоборот. В целом, Д. П. Никольский подробно рассмотрел смертность башкирского населения на примере трех волостей Екатеринбургского уезда Пермской губернии за 1870-1885 гг. [Никольский 1899: 185-198].

Демографические сведения по Оренбургской губернии за 1897-1899 гг. изучал М. М. Кенигсберг. Он писал, что на первом году жизни у мусульман губернии детей умирало меньше, чем у православных, а в возрасте 1-5 лет ситуация была обратной. М. М. Кенигсберг считал, что основной причиной детской смертности были эпидемические заболевания. Он отмечает, что до сих пор мусульмане «избегают прививать детям оспу» [Кенигсберг 1901: 64]. По подсчетам М. М. Кенигсберга, у мусульман до пожилого возраста доживало больше людей, нежели у православных. Данное явление он объяснял беспечностью, патриархальностью жизни, отсутствием у большинства из них трудных полевых работ, а также отсутствием пьянства и употребления алкоголя [Кенигсберг 1901: 63-65].

По губернским статистическим данным особенности смертности у мусульман (а также другого населения) Уфимской губернии в 1897-1911 гг. рассмотрел Э. И. Гиккель. Он на достаточно длительном отрезке времени показал, что в детском возрасте у мусульман умирало больше мальчиков, нежели девочек. Тогда как в рабочем возрасте женщины у них умирали в 1,5 раза больше, чем мужчины. Э. И. Гиккель писал, что у мусульманских детей на первом году жизни питание поставлено намного лучше, чем у православных, вследствие этого смертность у них в 2 раза ниже. Однако, как отмечал Э. И. Гиккель, дети у мусульман с двух лет поступали в обычные деревенские условия, с частым недоеданием и сильным распространением детских болезней. Поэтому со второго года, 
по его мнению, смертность детей у мусульман превышала аналогичные показатели у православных [Гиккель 1916: 25-75].

В советский период на примере Бирского и Белебеевского уездов Уфимской губернии смертность у башкир в пореформенный период рассмотрел М. В. Птуха. Его выводы весьма близки к расчетам Э. И. Гиккеля по мусульманскому населению губернии в целом [Птуха 1960: 240-278].

Однако в дальнейшем исследований проблем смертности у мусульман Южного Урала во второй половине XIX - начале $\mathrm{XX}$ в. практически не проводилось. Между тем, особенности смертности, важнейшего демографического показателя, у мусульман - одной из крупнейших групп населения региона, в том числе половозрастная структура умерших, вызывают значительный научный интерес в свете переходных явлений в традиционном обществе того времени.

В данной статье рассматриваются именно особенности половозрастной структуры умерших лиц мусульманского вероисповедания Оренбургской и Уфимской губерний во второй половине XIX - начале XX в.
Основными источниками стали статистические сведения, опубликованные Центральным статистическим комитетом (далее - ЦСК) МВД Российской империи с 1867 г. по 1910 г. Материалы для ЦСК представляли губернские статистические комитеты, которые в свою очередь соответствующие сведения получали от уездных и волостных правлений, мулл и т. д.

\section{Уровень смертности}

Смертность в рассматриваемый период оставалась достаточно высокой. Во время эпидемий уровень смертности резко повышался. Так, в 1890 г. во время эпидемии тифа он поднялся до 58 \%, в голодном 1891 г. составил $35 \%$, в первой половине 1892 г. - 63 \%. По контексту работы эти цифры относятся к Уфимской губернии [Никольский 1899: 171]. В Уфимской губернии с 1897 по 1911 г. коэффициент смертности всего населения за 15 лет в среднем составил 30,9 \%о, в некоторые годы далеко превышая средние показатели. Так, в 1904 г. он составил 39,3 \%о, в другие годы понижался, как в 1903 г. до 27 \%о [Гиккель 1916: 13, 14].

Таблица 1. Общие коэффициенты смертности мусульманского и всего населения Оренбургской и Уфимской губерний в начале ХХ в., в \%о

[Table 1. Crude mortality rates among Muslim and other populations of Orenburg and Ufa Governorates, per thousand. Early $20^{\text {th }}$ century]

\begin{tabular}{|l|c|c|c|c|}
\hline \multirow{2}{*}{ годы } & \multicolumn{2}{|c|}{ Оренбургская } & \multicolumn{2}{c|}{ Уфимкая } \\
\cline { 2 - 5 } & мусульмане & все население & мусульмане & все население \\
\hline 1901 & 29,1 & 36,6 & 25,7 & 28,6 \\
\hline 1903 & 30,5 & 35,2 & 25,2 & 27,5 \\
\hline 1904 & 37,0 & 43,2 & 38,6 & 39,5 \\
\hline 1905 & 31,8 & 37,3 & 31,3 & 33,6 \\
\hline 1906 & 27,5 & 37,7 & 26,1 & 29,1 \\
\hline 1907 & 30,9 & 41,4 & 26,3 & 32,8 \\
\hline 1909 & 28,0 & 41,0 & 31,0 & 32,2 \\
\hline 1910 & 31,9 & 42,0 & 28,1 & 31,6 \\
\hline В среднем & 30,8 & 39,3 & 29,0 & \\
\hline
\end{tabular}

Источники: [Статистика 1906б: XII, XIII; Статистика 1909: X, XI; Статистика 1911: X, XI; Статистика 1914a: X, XI; Статистика 1914б: X, XI; Статистика 1914в: X, XI; Статистика 1914г: X, XI; Статистика 1916: X, XI]

Примечание. Все вычисления коэффициентов, за исключением средних, сделаны Центральным статистическим комитетом МВД Российской империи.

Коэффициенты смертности мусульманского населения Оренбургской и Уфимской губерний в начале XX в. всегда были ниже,

чем коэффициенты смертности всего населения. Особенно показательны данные по Оренбургской губернии, где большинство 
населения составляли русские, у которых наблюдалась повышенная смертность детей младенческого возраста (таблица 1). Однако собственно уровень смертности населения, в том числе и у мусульман, в дореволюционный период оставался все же очень высоким.
Младенческая и детская смертность

Дореволюционные исследователи отмечали чрезвычайную детскую смертность у всех сословий и национальностей, в том числе у мусульман. Рассмотрим удельный вес детей до 5 лет в структуре смертности мусульманского населения Уфимской и Оренбургской губерний.

Таблица 2. Доля детей в возрасте от рождения до 5 лет в структуре смертности мусульманского населения Оренбургской и Уфимской губерний, в \%

[Table 2. Share of children aged 0 to 5 in the mortality structure of Muslim population.

Orenburg and Ufa Governorates. In percentage terms]

\begin{tabular}{|l|c|c|c|c|}
\hline \multirow{2}{*}{ годы } & \multicolumn{2}{|c|}{ Оренбургская губерния } & \multicolumn{2}{c|}{ Уфимская губерния } \\
\cline { 2 - 5 } & $\begin{array}{c}\text { Дети в возрасте } \\
\text { от рождения до } \\
\mathbf{1} \text { года }\end{array}$ & $\begin{array}{c}\text { Дети в возрасте } \\
\mathbf{1 - 5} \text { лет }\end{array}$ & $\begin{array}{c}\text { Дети в возрасте } \\
\text { от рождения до } \\
\mathbf{1} \text { года }\end{array}$ & $\begin{array}{c}\text { Дети в возрасте } \\
\mathbf{1 - 5} \text { лет }\end{array}$ \\
\hline 1867 & 23,9 & 24,6 & 21,6 & 24,8 \\
\hline 1870 & 22,6 & 24,2 & 24,4 & 22,9 \\
\hline 1885 & 15,6 & 34,5 & 23,1 & 28,8 \\
\hline 1890 & 17,2 & 39,8 & 25,1 & 32,5 \\
\hline 1896 & 24,2 & 34,9 & 29,7 & 33,3 \\
\hline 1900 & 22,8 & 30,8 & 30,3 & 26,2 \\
\hline 1905 & 22,2 & 33,2 & 24,6 & 33,9 \\
\hline 1910 & 22,9 & 28,3 & 28,8 & 26,4 \\
\hline
\end{tabular}

Источники: [Статистический 1872: 194-209; Статистический 1879: 184-191; Статистика 1890a: 142-143, 152-153; Статистика 1895: 142-143, 152-153; Статистика 1899: 142-143, 152-153; Статистика 1906a: 142-143, 152-153; Статистика 1914a: 160-163, 184-187; Статистика 1916: 160-163, 184-187].

У мусульман Оренбургской и Уфимской губерний младенческая смертность составляла от 15 до $30 \%$, в большинстве это пятая часть - четверть всех смертей (таблица 2). В 1897-1911 гг. у мусульманского населения Уфимской губернии 15,5 \% родившихся детей умирало на первом году жизни [Гиккель 1916: 50, 51].

У башкир Осинского уезда Пермской губернии в 1870-1880-е гг. смертность на первом году жизни не превышала $15 \%$, тогда как у православных доходила до 50 \%, у раскольников - до $60 \%$ [Соколов, Гребенщиков 1901: 49].

В 1870-1885 гг. у башкир Саринской, Карабольской и Кульмяковской волостей Екатеринбургского уезда Пермской губернии младенческая смертность составила $24,5 \%$, процент смертности в возрасте от рождения до 5 лет - 49 \% [Никольский 1899: 193]. Близкие к вышеуказанным цифры по смертности башкир на первом году жизни приводит М. В. Птуха [Птуха 1960: 245, 251].

Несколько иная ситуация складывалась у православного населения. В 1885 г. доля младенческой смертности у православного населения Оренбургской губернии составила 46,8 \%, Уфимской губернии - 48,3 \%, в 1910 г., соответственно, 42,8 и 44,4 \% [Статистика 1890a: 142-143, 152-153; Статистика 1916: 160-163, 184-187].

У православного населения Рождественской волости Екатеринбургского уезда Пермской губернии в 1880-1882 гг. доля смертности на первом году жизни составляла 66,9-68,8 \% [Голикова 2012: 43]. Таким образом, у православных, в отличие от мусульман, абсолютное большинство умерших в течение года лиц составляли младенцы на первом году жизни.

Как уже было сказано, на эту особенность младенческой смертности мусульманского и православного населения обращали внимание еще дореволюционные исследователи. Наиболее подробно данный вопрос осветили Н. А. Гурвич и Д. П. Никольский. Башкирки и татарки всюду вози- 
ли младенцев в закрытых тележках с собой и всегда имели возможность кормить их грудным молоком. Прикармливание детей начиналось примерно с девяти месяцев или даже позже. С этого времени и повышается уровень смертности детей. Однако прикармливание у башкир и татар было своевременным и более рациональным, нежели у русских, преимущественно белковыми веществами: коровьим молоком, салмой с молоком, чаем с молоком и т. д. Если у младенцев русской национальности в летний период отмечался понос и повышалась смертность, то у башкир и татар такого не наблюдалось [Памятная книжка 1878: 56; Никольский 1899: 194-195].

По мнению дореволюционных исследователей, по сравнению с православными, у мусульман Оренбургской и Уфимской губерний смертность детей в возрасте от одного года до 5 лет резко повышалась [Kенигсберг 1901: 63-65; Гиккель 1916: 25-75]. Однако, если брать смертность по годам в отдельности, то она на первом году жизни у мусульман всегда превышала смертность на втором или на третьем году жизни. Если же брать возрастную группу от 1 года до 5 лет, то смертность в этот период превышала (но не всегда) младенческую смертность.

После 5-летнего возраста смертность значительно снижалась. Л. Бергхольц утверждал, что у горных башкир-катайцев большая смертность в младенческом возрасте, тогда как с 4-5 лет она резко снижается. Дети, дожившие до этого возраста, могли, по его мнению, дожить до старости, так как в среднем возрасте смертность относительно низкая [Бергхольц 1893: 80]. Так, доля детей в возрасте 5-10 лет в структуре смертности мусульманского населения Оренбургской губернии в 1867 г. составляла 9,1 \%, Уфимской губернии - 10,4 \%, в 1870 г. - 6,1 и 7,0 \%, соответственно, в 1885 г. $-6,9$ и 6,7, в 1890 г. $-8,7$ и 7,0, в 1896 г. $-7,4$ и 7,1, в 1900 г. $-5,9$ и 5,5 , в 1905 г. $-8,0$ и 9,7, в 1910 г. $-7,2$ и $6,9 \%$ [Статистический 1872: 194-209; Статистический 1879: 184-191; Статистика 1890a: 142-143, 152-153; Статистика 1895: 142 143, 152-153; Статистика 1899: 142-143, 152-153; Статистика 1906a: 142-143, $152-$ 153; Статистика 1914a: 160-163, 184-187; Статистика 1916: 160-163, 184-187].
В 1867 г. более $60 \%$ умерших составляли дети в возрасте до 15 лет, при этом 46,4$48,5 \%$ (то есть чуть менее половины смертей) - дети до 5 лет [Статистический 1872: 194-209]. Это означает, что смертность детей определяла всю смертность населения в дореволюционный период. В последующие годы подобная ситуация в целом сохранялась.

У мусульман Оренбургской губернии дети в возрасте до 15 лет в составе умерших в 1870 г. составляли 56,1\%, в 1885 г. $59,4 \%$, в 1886 г. - 62,7\%, в 1887 г. $61,0 \%$, в 1888 г. -61,3\%, в 1889 г. $-55,8 \%$, в 1890 г. - 68,5\%, в 1893 г. - 60,6\%, в 1896 г. - 68,9\%, в 1897 г. - 74,2\%, в 1898 г. - 64,4\%, в 1899 г. - 65,6\%, в 1900 г. - 61,9\%, в 1901 г. - 67,3\%, в 1903 г. - 65,3\%, в 1904 г. - 66,4\%, в 1905 г. - 65,4\%, в 1906 г. - 63,3\%, в 1907 г. $-62,6 \%$, в 1910 г. - 61,1\%.

Аналогичное положение отмечается и у мусульманского населения Уфимской губернии. Дети в составе умерших составляли более $60 \%$, то есть около двух третей. Лишь в 1870 г. данный показатель был ниже - 57,5\%, а в некоторые годы - выше 70 \%: в 1885 г. - 70,6 \%, в 1896 г. - 72,2\%, в 1897 г. - 70,4 \%, в 1904 г. - 71,8\%, в 1905 г. - 71,0\%.

У православного населения губерний данный процент обычно составлял свыше $70 \%$. Так, в 1885 г. доля детей в возрасте до 15 лет в составе умерших у православного населения Оренбургской губернии составила $73 \%$, Уфимской губернии - 70,6\%, в 1910 г., соответственно, 72,7 и 72,7 \% [Статистический 1879: 184-191; Статистика 1890а: 142-143, 152-153; Статистика 1890б: 142-143, 152-153; Статистика 1891: 142143, 152-153; Статистика 1892: 142-143, 152-153; Статистика 1893: 142-143, 152153; Статистика 1895: 142-143, 152-153; Статистика 1897: 142-143, 152-153; Статистика 1899: 142-143, 152-153; Статистика 1900: 142-143, 152-153; Статистика 1903: 142-143, 152-153; Статистика 1904: 142143, 152-153; Статистика 1906а: 142-143, 152-153; Статистика 1906б: 160-161, 184185; Статистика 1909: 160-161, 184-185; Статистика 1911: 160-163, 184-187; Статистика 1914a: 160-163, 184-187; Статистика 1914б: 160-163, 184-187; Статистика 1914в: 160-163, 184-187; Статистика 1916: 160$163,184-187]$. 
В 1897-1911 гг. в Уфимской губернии удельный вес детей в возрасте до 10 лет среди умерших у мусульман составила $62,2 \%$, у православных - 71,2\%, у всего населения - 66,5\% [Гиккель 1916: 36]. Таким образом, абсолютное большинство умерших в дореволюционный период у всех национальностей, в том числе у мусульман башкир, татар, мишарей и тептярей, составляли дети в возрасте до 15 лет.
Мальчиков в детском возрасте у мусульман, как и у остальных, умирало больше, чем девочек. Как уже говорилось, Д. П. Никольский отмечал в трех башкирских волостях Екатеринбургского уезда Пермской губернии в 1870-1885 гг. другую тенденцию, когда девочек умирало больше, чем мальчиков. Однако показатели по мусульманскому населению Оренбургской и Уфимской губерний не подтверждают это мнение.

Таблица 3. Половое соотношение умерших лиц в возрасте до 15 лет у мусульманского населения Оренбургской и Уфимской губерний, в \%

[Table 3. Gender ratio among deceased Muslim residents aged 0 to 15. Orenburg and Ufa Governorates. In percentage terms]

\begin{tabular}{|l|c|c|c|c|c|c|}
\hline \multirow{2}{*}{ годы } & \multicolumn{3}{|c|}{ Оренбургская губерния } & \multicolumn{3}{c|}{ Уфимская губерния } \\
\cline { 2 - 7 } & мужчины & женщины & всего & мужчины & женщины & всего \\
\hline 1867 & 51,1 & 48,9 & 100 & 51,4 & 48,6 & 100 \\
\hline 1870 & 52,8 & 47,2 & 100 & 52,6 & 47,4 & 100 \\
\hline 1885 & 53,2 & 46,8 & 100 & 53,2 & 46,8 & 100 \\
\hline 1890 & 53,0 & 47,0 & 100 & 52,0 & 48,0 & 100 \\
\hline 1896 & 52,6 & 47,4 & 100 & 51,4 & 48,6 & 100 \\
\hline 1900 & 52,9 & 47,1 & 100 & 51,5 & 48,5 & 100 \\
\hline 1905 & 51,8 & 48,2 & 100 & 51,8 & 48,2 & 100 \\
\hline 1910 & 52,2 & 47,8 & 100 & 52,3 & 47,7 & 100 \\
\hline
\end{tabular}

Источники: [Статистический 1872: 194-209; Статистический 1879: 184-191; Статистика 1890a: 142-143, 152-153; Статистика 1895: 142-143, 152-153; Статистика 1899: 142-143, 152-153; Статистика 1906a: 142-143, 152-153; Статистика 1914a: 160-163, 184-187; Статистика 1916: 160$163,184-187]$.

Во все годы, как видно, мальчиков в возрасте до 15 лет умирало больше, чем девочек (таблица 3). Резкое снижение смертности населения происходит после 10-летнего возраста. В этот период организм детей становился достаточно крепким. Пережив опасные ранние годы, отныне башкиры могли вполне благополучно дожить до глубокой старости. С каждой возрастной группой доля умерших снижалась.

Смертность среди взрослого населения и лиц пожилого возраста

Как уже говорилось, если до 15-летнего возраста среди умерших преобладали мальчики (особенно заметно - в младенческом возрасте), то после 15 лет вплоть до 45 лет у мусульман положение меняется на противоположное. Впрочем, такое положение было характерно и для всего населения России [Вербицкая 2009: 133].

Ранее отмечалось, что Д. П. Никольский писал о преобладании женской смертности у башкир Екатеринбургского уезда Пермской губернии в фертильном возрасте, с 26 лет [Никольский 1899: 196-197]. О преобладании лиц женского пола от 5 до 60 лет в структуре смертности мусульман Оренбургской губернии в конце XIX в. писал М. М. Кенигсберг [Кенигсберг 1901: 89].

Э. И. Гиккель показал, что на протяжении 14 лет (1897-1911 гг.) у мусульман Уфимской губернии число лиц женского пола в составе умерших превышало число лиц мужского пола в возрасте от 5 до 50 лет. В возрасте 15-20 лет женщин умирало почти в 2 раза больше, чем парней той же возрастной категории. В 20-50 лет на 100 умерших женщин приходилось 62 мужчины [Гиккель 1916: 40].

Однако следует заметить, что превышение числа женщин в репродуктивном возрасте (15-50 лет) среди умерших мусульман не всегда было фактом. Так, в 1867 г. в Оренбургской губернии мусульман-муж- 
чин в возрасте 15-50 лет умерло больше, чем женщин [Статистический 1872: 194 209]. Однако в большинстве своем женщин в возрасте 15-45 лет (в иные годы - до 40 лет) умирало больше, чем мужчин. Так, в Уфимской губернии в 1910 г. женщин в возрасте 15-20 лет умерло в 2,1 раза больше, чем мужчин, в 1903 г. - в 1,9 раза, в 1905 г. - в 1,8 раза, 1898, 1901, 1904, 1906 гг. - в 1,7 раза, в 1885, 1896 гг. - в 1,6 раза, в 1893 г. - в 1,5 раза, в 1887 г. в 1,3 раза, в 1897 г. - в 1,2 раза [Статистика 1890a: 152-153; Статистика 1891: 152-153; Статистика 1897: 152-153; Статистика 1899: 152-153; Статистика 1900: 152-153; Статистика 1903: 152-153; Статистика 1906б: 184-185; Статистика 1909: 184-185; Статистика 1911: 184-187; Статистика 1914a: 184-187; Статистика 1914б: 184-187; Статистика 1916: 184-187].

В Оренбургской губернии: в 1897 г. — в 2 раза, в 1910 г. - в 1,9 раза, в 1870,1904 , 1905 гг. - в 1,7 раза, в 1901, 1906 гг. - в 1,6 раза, в $1885,1896,1903,1907$ гг. - в 1,4 раза, в 1890, 1893 гг. - в 1,3 раза, в 1887 г. - в 1,2 раза и т. д. [Статистический 1879: 184-191; Статистика 1890a: 142-143; Статистика 1891: 142-143; Статистика 1895: 142-143; Статистика 1897: 142-143; Статистика 1899: 142-143; Статистика 1900: 142-143; Статистика 1906б: 160-161; Статистика 1909: 160-161; Статистика 1911: 160-163; Статистика 1914a: 160-163; Статистика 19146: 160-163; Статистика 1914в: 160-163; Статистика 1916: 160-163].

Аналогичное положение наблюдаем и в других возрастных группах до 45 лет. С 35 лет начинает повышаться и мужская смертность, а с 45 лет (в иные годы - с 40 лет) она уже превышала женскую [Статистический 1879: 184-191; Статистика 1890a: 142-143, 152-153; Статистика 1891: 142-143, 152-153; Статистика 1895: 142 143; Статистика 1897: 142-143, 152-153; Статистика 1899: 142-143, 152-153; Статистика 1900: 142-143, 152-153; Статистика 1903: 152-153; Статистика 1906a: 160-161, 184-185; Статистика 1909: 160-161, 184185; Статистика 1911: 160-163, 184-187; Статистика 1914a: 160-163; Статистика 1914б: 160-163, 184-187; Статистика 1914в: 160-163, 184-187; Статистика 1916: 160 163, 184-187].
Французский путешественник П. Лаббе утверждал, что множество башкирок умирало от родов [Лаббе 2017: 131]. Есть большой соблазн отнести повышенную женскую смертность в репродуктивном возрасте на неблагополучные беременность и роды. Такие точки зрения уже высказывались в литературе [История 2006: 23].

Однако исследования по русскому горнозаводскому населению Урала показали, что роды как причина женской смертности во второй половине XIX в. не занимали лидирующее положение, а входили лишь в первую десятку [Голикова 2001: 113].

Как обстояло дело у мусульманских народов Приуралья - башкир и татар, остается неизвестным. М. М. Кенигсберг связывал повышенную смертность женщин с их положением в семье: полным порабощением, тяжелой работой, замкнутой домашней жизнью, полигинией [Кенигсберг 1901: 89].

По мнению М. М. Кенигсберга, в мусульманском населении Оренбургской губернии до преклонных лет (старше 60 лет) гораздо больше доживали мужчины, нежели женщины. Это явление объяснялось повышенной смертностью женщин в предыдущих возрастных группах [Кенигсберг 1901: 89].

П. Лаббе считал, что изнуренная непосильным трудом башкирка быстро стареет. Он писал, что практически не встречал пожилых женщин [Лаббе 2017: 131].

П. Л. Юдин писал, что предельный возраст у башкир - 50-60 лет, и акцентировал свое внимание на мужской смертности [Юдин 1890: 6]. Как показывают материалы Всеобщей переписи 1897 г., после 60-летнего возраста у башкир в обеих губерниях, a также у мишарей и тептярей Оренбургской губернии отмечалось преобладание мужчин, впрочем, как и во всех других возрастных группах (за некоторыми исключениями). Тогда как у татар, мещеряков и тептярей Уфимской, татар Оренбургской губерний в пожилом возрасте преобладали женщины [Первая 1904a: 72-75; Первая 1904б: 58-61].

Отмеченные выше особенности смертности населения: высокий ее уровень в младенческом и детском возрастах, повышенная смертность женщин фертильного возраста, сменяющаяся после 45 лет увеличением мужской смертности, согласно О. М. Вербицкой, являются характерными 
чертами традиционного демографического режима. Высокий уровень детской смертности обуславливал в компенсаторных целях и высокий уровень рождаемости в дореволюционный период [Вербицкая 2009: 82-84].

\section{Заключение}

Смертность у мусульманских народов Южного Урала - башкир, татар, тептярей и мишарей в рассматриваемый период оставалась очень высокой. Большинство смертей приходилось на детей до 10 лет, что, в конце концов, снижало общее число детей в семье. Тем самым регулировались демографические процессы, в первую очередь уровень детности семей. Приведенные статистические сведения показывают, что, несмотря на высокую смертность мусульман, она была не выше, а ниже смертности

Источники
Первая 1904a - Первая всеобщая перепись населения Российской империи, 1897 г. T. XXVIII. Оренбургская губерния. СПб.: изд. ЦСК МВД, 1904. 173 с.

Первая 1904б - Первая всеобщая перепись населения Российской империи, 1897 г. T. XLV. Уфимская губерния. Тетрадь 2. СПб.: изд. ЦСК МВД, 1904. 189 с.

Статистика $1890 \mathrm{a}-$ Статистика Российской империи. Т. 11. Движение населения в Европейской России за 1885 год. СПб.: изд. ЦСК МВД, 1890. VIII, $211 \mathrm{c.}$

Статистика $1890 б$ - Статистика Российской империи. Т. 12. Движение населения в Европейской России за 1886 год. СПб.: изд. ЦСК МВД, 1890. 16, $211 \mathrm{c.}$

Статистика 1891 - Статистика Российской империи. Т. 18. Движение населения в Европейской России за 1887 год. СПб.: Тип. и фототип. В. И. Штейна, 1891. 30, 211 с.

Статистика 1892 - Статистика Российской империи. Т. 21. Движение населения в Европейской России за 1888 год. СПб.: Тип. и фототип. В. И. Штейна, 1892. 10, 211 с.

Статистика 1893 - Статистика Российской империи. Т. 24. Движение населения в Европейской России за 1889 год. СПб.: Тип. и фототип. В. И. Штейна, 1893. VI, 211 с.

Статистика 1895 - Статистика Российской империи. Т. 33. Движение населения в Европейской России за 1890 год. СПб.: Типо-литография П. П. Сойкина, 1895. VI, 211 с. остального населения. Повышенная детская смертность, доходившая иногда до 70 \%о, свидетельствует о том, что так называемый демографический переход (то есть переход от традиционной, многодетной семьи, характерными чертами которой были высокая рождаемость и высокая смертность населения, к современной, малодетной) в исследуемый период еще не начался. Повышенная женская смертность в фертильном возрасте, высокая мужская смертность после 45 лет - все эти показатели являются характерными чертами традиционного демографического порядка. Положительные тенденции в смертности мусульманского населения, очень слабо проявившиеся в начале XX в., в тот период еще не меняли кардинально ситуацию.

Статистика 1897 - Статистика Российской империи. Т. 41. Движение населения в Европейской России за 1893 год. СПб.: Типо-литография П. И. Бабкина, 1897. VII, 211 с.

Статистика 1899 - Статистика Российской империи. Т. 48. Движение населения в Европейской России за 1896 год. СПб.: Тип. «Товарищество художественной печати», 1899. VI, $211 \mathrm{c}$.

Статистика 1900 - Статистика Российской империи. Т. 50. Движение населения в Европейской России за 1897 год. СПб.: изд. ЦСК МВД, 1900. XVI, 211 с.

Статистика 1903 - Статистика Российской империи. Т. 56. Движение населения в Европейской России за 1898 год. СПб.: Тип. «Товарищество художественной печати», 1903. VI, $211 \mathrm{c}$.

Статистика 1904 - Статистика Российской империи. Т. 58. Движение населения в Европейской России за 1899 год. СПб.: Тип. «Товарищество художественной печати», 1904. VI, $211 \mathrm{c}$.

Статистика 1906а - Статистика Российской империи. Т. 62. Движение населения в Европейской России за 1900 год. СПб.: Типо-литография М. Я. Минкова, 1906. Х, 211 с.

Статистика 1906 - Статистика Российской империи. Т. 63. Движение населения в Европейской России за 1901 год. СПб.: Тип. «Пушкинская Скоропечатня», 1906. XXI, 248 с.

Статистика 1909 - Статистика Российской империи. Т. 70. Движение населения в Европейской России и в двух губерниях Сибири: 
Енисейской и Тобольской и Семипалатинской областях за 1903 год. СПб.: Тип. Т-ва «Ш. Буссель Н-ки», 1909. XXIII, 277 с.

Статистика 1911 - Статистика Российской империи. Т. 74. Движение населения в Европейской России и в двух губерниях Сибири: Иркутской и Енисейской за 1904 год. СПб.: Тип. Т-ва «Ш. Буссель Н-ки», 1911. ХХІ, $277 \mathrm{c}$.

Статистика 1914a - Статистика Российской империи. Т. 84. Движение населения в Европейской России за 1905 год. Пг.: Тип. штаба Петрогр. Воен. округа, 1914. XVI, 249 с.

Статистика 19146 - Статистика Российской империи. Т. 85. Движение населения в Европейской России за 1906 год. Пг.: Типография штаба Петроградского военного округа, 1914. XVI, 249 c.

Статистика 1914в - Статистика Российской империи. Т. 87. Движение населения в Европейской России за 1907 год. Пг.: Типогра-

\section{Sources}

Russian Imperial Census of 1897. Vol. XLV: Ufa Governorate. Part 2. St. Petersburg: Central Statistical Committee, 189 p. (In Russ.)

Russian Imperial Census of 1897. Vol. XXVIII: Orenburg Governorate. St. Petersburg: Central Statistical Committee, 1904. 173 p. (In Russ.)

Statistical Chronicles of the Russian Empire. Series II. Vol. 14: Population Movement in European Russia, 1870. St. Petersburg, 1879. XXII, 285 p. (In Russ.)

Statistical Chronicles of the Russian Empire. Series II. Vol. 8: Population Movement in European Russia, 1867. St. Petersburg: Ministry of Internal Affairs, 1872. X, 461 p. (In Russ.)

Statistics of the Russian Empire. Vol. 11: Population Movement in European Russia, 1885. St. Petersburg: Central Statistical Committee, 1890. VIII, 211 p. (In Russ.)

Statistics of the Russian Empire. Vol. 12: Population Movement in European Russia, 1886. St. Petersburg: Central Statistical Committee, 1890. 16, 211 p. (In Russ.)

Statistics of the Russian Empire. Vol. 18. Population Movement in European Russia, 1887. St. Petersburg: V. I. Stein, 1891. 30, 211 p. (In Russ.)

Statistics of the Russian Empire. Vol. 21: Population Movement in European Russia, 1888. St. Petersburg: V. I. Stein, 1892. 10, 211 p. (In Russ.) фия штаба Петроградского военного округа, 1914. XVI, 249 c.

Статистика 1914г - Статистика Российской империи. Т. 91. Движение населения в Европейской России за 1909 год. Пг.: Типография штаба Петроградского военного округа, 1914. XVI, 249 c.

Статистика 1916 - Статистика Российской империи. Т. 93. Движение населения в Европейской России за 1910 год. Пг.: Типография штаба Петроградского военного округа, 1916. XVI, 249 c.

Статистический 1872 - Статистический временник Российской империи. Серия II. Вып. 8. Движение населения в Российской империи за 1867 год. СПб.: Типография МВД, 1872. Х, $461 \mathrm{c.}$

Статистический 1879 - Статистический временник Российской империи. Серия II. Вып. 14. Движение населения в Российской империи за 1870 год. СПб.: [б. и.], 1879. XXII, 285 с.

Statistics of the Russian Empire. Vol. 24: Population Movement in European Russia, 1889. St. Petersburg: V. I. Stein, 1893. VI, 211 p. (In Russ.)

Statistics of the Russian Empire. Vol. 33: Population Movement in European Russia, 1890. St. Petersburg: P. P. Soykin, 1895. VI, 211 p. (In Russ.)

Statistics of the Russian Empire. Vol. 41: Population Movement in European Russia, 1893. St. Petersburg: P. I. Babkin, 1897. VII, 211 p. (In Russ.)

Statistics of the Russian Empire. Vol. 48: Population Movement in European Russia, 1896. St. Petersburg: Tovarishchestvo Khudozhestvennoy Pechati, 1899. VI, 211 p. (In Russ.)

Statistics of the Russian Empire. Vol. 50: Population Movement in European Russia, 1897. St. Petersburg: Central Statistical Committee, 1900. XVI, 211 p. (In Russ.)

Statistics of the Russian Empire. Vol. 56: Population Movement in European Russia, 1898. St. Petersburg: Tovarishchestvo Khudozhestvennoy Pechati, 1903. VI, 211 p. (In Russ.)

Statistics of the Russian Empire. Vol. 58: Population Movement in European Russia, 1899. St. Petersburg: Tovarishchestvo Khudozhestvennoy Pechati, 1904. VI, 211 p. (In Russ.) 
Statistics of the Russian Empire. Vol. 62: Population Movement in European Russia, 1900. St. Petersburg: M. Ya. Minkov, 1906. X, 211 p. (In Russ.)

Statistics of the Russian Empire. Vol. 63: Population Movement in European Russia, 1901. St. Petersburg: Pushkinskaya Skoropechatnya, 1906. XXI, 248 p. (In Russ.)

Statistics of the Russian Empire. Vol. 70: Population Movement in European Russia and Two Siberian Governorates (Yeniseysk and Tobolsk Ones) + Semipalatinsk Oblast, 1903. St. Petersburg: Ch. Busselle and Co., 1909. XXIII, 277 p. (In Russ.)

Statistics of the Russian Empire. Vol. 74: Population Movement in European Russia and Two Siberian Governorates (Irkutsk and Yeniseysk Ones), 1904. St. Petersburg: Ch. Busselle and Co., 1911. XXI, 277 p. (In Russ.)

\section{Литература}

Бергхольц 1893 - Бергхольи Л. Горные башкиры-катайцы // Этнографическое обозрение 1893. № 3-4. С. 74-84.

Вербицкая 2009 - Вербицкая О. М. Российская сельская семья в 1897-1959 гг. (историко-демографический аспект). М.; Тула: Гриф и К, 2009. 296 с.

Гиккель 1916 - Гиккель Э. И. Санитарно-статистические сведения по Уфимской губернии. Вып. 1. Очерк движения населения Уфимской губернии в 1897-1911 гг. Уфа: Печать, $1916.80 \mathrm{c}$

Голикова 2012 - Голикова С. В. Детская смертность в Пермской губернии (вторая половина XIX - начало XX в.): источниковедческий и методический аспекты. Екатеринбург: РИО УрО РАН, 2012. 176 с.

Голикова 2001 - Голикова С. В. Семья горнозаводского населения Урала XVIII-XIX веков: демографические процессы и традиции. Екатеринбург: УрО РАН, 2001. 196 с.

История 2006 - История Башкортостана во второй половине XIX - начале XX века. В 2 т.: Т. I. Уфа: Гилем, 2006. 240 с.

Кенигсберг 1901 - Кенигсберг М. М. Санитарное состояние Оренбургской губернии по данным естественного движения за трехлетие 1897-1899 гг. Т. 1. Ч. 1. Оренбург: Губернская типо-литография, 1901. 114 с.

Лаббе 2017 - Лаббе П. По дорогам России от Волги до Урала: пер. с фр. А. Ш. Губайдуллиной и Л. Ф. Сахибгареевой под ред. И. В. Кучумова. М.: Paulsen, 2017. 224 с.
Statistics of the Russian Empire. Vol. 84: Population Movement in European Russia, 1905. Petrograd: Headquarters of Petrograd Military District, 1914. XVI, 249 p. (In Russ.)

Statistics of the Russian Empire. Vol. 85: Population Movement in European Russia, 1906. Petrograd: Headquarters of Petrograd Military District, 1914. XVI, 249 p. (In Russ.)

Statistics of the Russian Empire. Vol. 87: Population Movement in European Russia, 1907. Petrograd: Headquarters of Petrograd Military District, 1914. XVI, 249 p. (In Russ.)

Statistics of the Russian Empire. Vol. 91: Population Movement in European Russia, 1909. Petrograd: Headquarters of Petrograd Military District, 1914. XVI, 249 p. (In Russ.)

Statistics of the Russian Empire. Vol. 93: Population Movement in European Russia, 1910. Petrograd: Headquarters of Petrograd Military District, 1916. XVI, 249 p. (In Russ.)

Никольский 1899 - Никольский Д. П. Башкиры. Этнографическое и санитарно-антропологическое исследование: диссертация на степень доктора медицины лекаря Дмитрия Петровича Никольского. СПб.: Тип. П. П. Сойкина, $1899.317 \mathrm{c}$.

Памятная книжка 1878 - Памятная книжка Уфимской губернии на 1878 год / сост. В. А. Новиков, Н. А. Гурвич. Уфа: изд. попечит. о бедных ком-та, 1878. 177 с.

Птуха 1960 - Птуха М. В. Очерки по статистике населения. М.: Госстатиздат, 1960. 459 с.

Сабанеев 1873 - Сабанеев Л. Очерки Зауралья и степное хозяйство на башкирских землях. М.: Тип. В. Готье, 1873. 162 с.

Скалозубов 1893 - Скалозубов Н. Л. Очерк экономического положения башкирского населения Красноуфимского уезда Пермской губернии. Пермь: Тип. Губернской земской управы, 1893. 158 с.

Соколов, Гребенщиков $1901-$ Соколов Д. А., Гребенщиков В. И. Смертность в России и борьба с нею. СПб.: тип. М. М. Стасюлевича, 1901.77 с.

Успенский 1982 - Успенский Г. И. От Оренбурга до Уфы. Очерки. Уфа: Башкирское кн. изд-во, 1982. 288 с.

Флоринский 1874 - Флоринский В. Башкирия и башкиры. Путевые заметки // Вестник Европы. 1874. Кн. 12. С. 723-765.

Юдин 1890 - Юдин П. Л. Башкиры (бытовой очерк) // Оренбургские губернские ведомости. 1890. № 36. С. 5-6. 


\section{References}

Bergholtz L. The Katai: Bashkir highlanders. Etnograficheskoe obozrenie. 1893. No. 3-4. Pp. 7484. (In Russ.)

Florinsky V. Bashkiria and the Bashkirs: travel notes. Vestnik Evropy. 1874. Vol. 12. Pp. 723765. (In Russ.)

Golikova S. V. Child Mortality in Perm Governorate, Mid- $19^{\text {th }}-$ Early $20^{\text {th }}$ Centuries: Historiographic and Methodological Aspects Revisited. Yekaterinburg: Ural Branch of RAS, 2012. 176 p. (In Russ.)

Golikova S. V. Mining and Metallurgical Population of the Southern Urals. $18^{\text {th }}-19^{\text {th }}$ Centuries. Family: Demographic Processes and Traditions. Yekaterinburg: Ural Branch of RAS, 2001. 196 p. (In Russ.)

Gvozdikova I. M., Rodnov M. I., Khisamitdinova F. G. (eds.) History of Bashkortostan: Mid$19^{\text {th }}-$ Early $20^{\text {th }}$ Centuries. In 2 vols. Vol. I. Ufa: Gilem, 2006. 240 p. (In Russ.)

Hickel E. I. Ufa Governorate: Sanitary and Statistical Data. Vol. 1: Essay on Population Movement in Ufa Governorate, 1897-1911. Ufa: Pechat, 1916. 80 p. (In Russ.)

Kenigsberg M. M. Orenburg Governorate: Sanitary Conditions Resulting from Population Movement in 1897-1899. Vol. 1. Part 1. Orenburg: Orenburg Governorate Press, 1901. 114 p. (In Russ.)

Labbé P. (Along) Great Roads of Russia: from the Volga to the Urals. A. Gubaydullina, L. Sakhib- gareeva (transl.); I. Kuchumov (ed.). Moscow: Paulsen, 2017. 224 p. (In Russ.)

Nikolsky D. P. The Bashkirs: An Ethnographic, Sanitary and Anthropological Study. M.D. thesis. St. Petersburg: P. P. Soykin, 1899. 317 p. (In Russ.)

Novikov V. A., Gurvich N. A. (comps.) Memorial Book of Ufa Governorate: 1878. Ufa: Poverty Relieving Committee, 1878, 177 p. (In Russ.)

Ptukha M. V. Essays on Population Statistics. Moscow: Gosstatizdat, 1960. 459 p. (In Russ.)

Sabaneev L. Essays on the Transurals, and Steppe Economy in Bashkir Lands. Moscow: V. Gautier, 1873. 162 p. (In Russ.)

Skalozubov N. L. Krasnoufimsky Uyezd of Perm Governorate: An Essay on Economic Conditions of the Bashkir Population. Perm: Governorate Executive Office of Elective Districts, 1893. 158 p. (In Russ.)

Sokolov D. A., Grebenshchikov V. I. Mortality and Its Control in Russia. St. Petersburg: M. M. Stasyulevich, 1901. 77 p. (In Russ.)

Uspensky G. I. From Orenburg to Ufa. Essays. Ufa: Bashkir Book Publ., 1982. 288 p. (In Russ.)

Verbitskaya O. M. Russian Rural Family in 18971959: Historical and Demographic Aspects Revisited. Moscow; Tula: Grif and Co., 2009. 296 p. (In Russ.)

Yudin P. L. The Bashkirs: an essay on household life. Orenburgskie gubernskie vedomosti. 1890. No. 36. Pp. 5-6. (In Russ.) 